\title{
RESEARCH ENHANCING THE QUALITY OF TEACHING: ECONOMETRIC EVIDENCE FROM BRAZIL
}

\author{
Eduardo de Carvalho Andrade * \\ Bruno de Paula Rocha ${ }^{\dagger}$
}

\begin{abstract}
Resumo
Este artigo reporta evidência de que as atividades de pesquisa tendem a melhorar a avaliação recebida dos professores pelos alunos (SET) com uma defasagem temporal. Além disso, os resultados sugerem que as atividades de pesquisa sejam complementares às atividades de ensino. As atividades de pesquisa parecem afetar a qualidade do ensino no momento em que são realizadas, indicando um ganho na realização conjunta das atividades de ensino e pesquisa.
\end{abstract}

Palavras-chave: Avaliação de Professores por Alunos; Modelos de Dados em Painel; Pesquisa; Qualidade de Ensino.

\begin{abstract}
We find evidence that the process of doing research increases the professor's knowledge and enhances the student evaluation of teaching (SET) with a lag. Moreover, the results suggest that research activity seems to be complementary to teaching. The research activity seems to increase the quality of teaching at the moment that it is put in place, i.e., both activities can be seen as 'mutually reinforcing'.
\end{abstract}

Keywords: Student Evaluation Score; Fixed-Effect Model; Research; and Quality of Teaching.

JEL classification: A20; A22; I20

DOI: http://dx.doi.org/10.11606/1413-8050/ea144832

\footnotetext{
* Apex Capital Ltda. E-mail: eduardo.andrade@apexcapital.com.br

+ Centro de Engenharia, Modelagem e Ciências Sociais Aplicadas, Universidade Federal do ABC

(UFABC). E-mail: rocha.b@ufabc.edu.br
} 


\section{Introduction}

Professors at most universities (and many colleges) tend to have their work evaluated in great length on two dimensions for purposes of promotion, tenure and salary increases. First, the quality of their research, measured by the number of articles published in peer-review and high-prestige academic journals, is a key variable (Fairweather 2002). Second, it is common for students to evaluate their professors at the end of the courses (Becker \& Watts 1999). The results of the student evaluation of teaching (SET) are considered an instrument to assess the quality of a professor's teaching, and are used by these institutions for purposes of promotion of the professors (McPherson et al. 2009).

Some argue that research negatively affects the quality of teaching. Both activities demand time and spending long hours dedicated to one activity may happen at the expense of the other. The traditional emphasis on classroom teaching is no longer available because faculty receives greater rewards for research productivity and publication (Harmon 2006, Binder et al. 2012). In fact, this seems to be the perception of the academic professionals. In the 1989 National Survey of Faculty, more than half answered positively to the question of wheter the 'pressure to publish reduces the quality of teaching at any university' (Boyer 1990). Others argue in the opposite direction. Research and teaching are complementary activities in a way that 'excellence in scholarship feeds excellence in the classroom' (Binder et al. 2012), they are 'mutually reinforcing' and 'the best scholars are the best teachers' (Fairweather 2002). Professors may spend less time in other activities such as administrative tasks, grant writing, student advising, paid consulting or leisure, and be simultaneously productive in teaching and research. ${ }^{1}$ Moreover, successful research can increase the professor's confidence and his performance in the classroom (Zaman 2004).

The literature examining the teaching-research nexus is vast. ${ }^{2}$ However, the overwhelming majority of the empirical findings are based on simple correlation analysis. ${ }^{3}$ Furthermore, most articles relating teaching and research bring evidence to universities in developed countries (Zaman 2004). This article aims to fill these gaps using a new large panel data from a private higher education institution in Brazil to estimate a fixed-effect model in order to test how research (measured by the number/quality of publications) affects the quality of teaching (measured by the SET). We examine this possible connection in two different ways.

On one hand, after mastering more subjects, which is verified by a greater number/quality of publications, it is possible that the professors improve their teaching skills, with positive effects on the SET, as they introduce 'researchbased material into their classroom instruction' (Fairweather 2002). It may take some time for the materialization of this effect. In this case, the variable past number/quality of publications should positively affect the SET today. On the other hand, the product of the activity of research today will take place only in the future as the process of preparing, writing, submitting and having the paper accepted and published by an academic journal takes time. Therefore, a proxy for the research activity today is the number/quality publi-

\footnotetext{
${ }^{1}$ Link et al. (2008) examine how tenure and promotion affect the allocation of time.

${ }^{2}$ A detailed discussion can be seen in Zaman (2004).

${ }^{3}$ Two recent exceptions are the use of non-parametric efficiency measures in De De Witte et al. (2013) and the OLS fixed effects regressions in Ginsburg \& Miles (2015).
} 
cations in the future. Hence, this variable could positively or negatively affect the quality of teaching and the SET today, depending on whether both activities are complementary or substitutive.

The remainder of the article is organized as follows. The next section presents the dataset and the econometric model employed to access the relationship between research and quality of teaching. Section 3 presents the most important empirical results and section 4 contains the conclusions. The tables can be found in the Appendix Appendix A.

\section{Data and Methodology}

We obtained the panel data from Insper Academic Records Office. Insper (Institute of Education and Research) is a Brazilian institution for education and research, acting in the fields of Business, Economics, Law and Engineering. The dataset covers fourteen semesters from the second semester of 2005 to the first semester of 2012, encompassing 1,230 undergraduate courses in Economics and Business taught by 154 professors in 115 different disciplines.

Some professors taught more than one course in the same semester during this period. This fact precludes the use of panel data techniques when using the professor as the unit of analysis. Therefore, we use the pair professor/discipline as the unit of analysis. If this unit occured more than once in the semester, we averaged them. Hence, the number of observations in the data is 928 and there are 240 pairs of professor/discipline.

In order to access the relation between research and the quality of teaching, we estimate a fixed-effect regression model. The control for professor's unobservable specific effects is important, since they are probably correlated with the professor's teaching and research skills. It may be argued, for example, that the quality of a professor's course depends on individual attributes such as motivation and communication specific skills. The same individual attributes are probably also important in determining the quality of the professor's research. Therefore, the omission of these specific factors would introduce biases in the estimation of the real research-teaching relationship. ${ }^{4}$ Thus, we estimated the following model:

$$
Y_{i t}=\alpha+u_{i}+\gamma_{t}+Z_{i t} \beta_{1}+X_{i t} \beta_{2}+\epsilon_{i t},
$$

where the dependent variable $Y_{i t}$ is the SET score of the pair professor/ discipline ' $i$ ' in semester ' $t$ ',$\alpha$ is a constant, $u_{i}$ is the pair professor/discipline specific effect, $\gamma_{t}$ is the semester-specific effect, $Z_{i} t$ is a vector with leads and lags of the variable of interest the number/quality of publications, $\beta_{1}$ is a vector with the coefficients of interest, $X_{i t}$ is a vector that includes control variables with its corresponding coefficients in vector $\beta_{2}$ and $\epsilon_{i t}$ is the error term which is assumed to be normally distributed.

The dependent variable is the average of all answers in the SET form (hereafter referred to as EVAL), which is the variable used by Insper to evaluate the quality of a professor's teaching for purposes of promotion. A group of professionals (other than the instructors) distributes the SET forms without prior announcement twice during the semester. The evaluations occur right before

\footnotetext{
${ }^{4}$ For a formal description of fixed-effect models for panel data, see Greene (2008).
} 
the mid-term and final exams. In our analysis, we only used the results obtained in the last evaluation. The SET form comprises 13 questions designed to evaluate different dimensions of the quality of teaching in the respective course. ${ }^{5}$ For each question, the answers range from 1 to 4 , where a higher value indicates a better evaluation. In Table A.1 of the appendix, we present the descriptive statistics of the dependent and explanatory variables used in the analysis.

The key variable, with leads and lags in vector $Z_{i t}$, is the number/quality of publications (hereafter referred to as $\mathrm{RSCH}$ ), which is the variable used by Insper to evaluate the quality of the research for purposes of promotion; the greater the $\mathrm{RSCH}$ is, the greater the number/quality of publications. The data on RSCH is annual, while for all other variables are on semester-based. The annual data on RSCH was used for both semesters of that year.

It is important to explain how the variable $\mathrm{RSCH}$ is calculated. The academic journals are stratified into seven categories, from A1 to B5, depending on its impact factors. As can be seen in column 2 of Table A.2, in Economics, a journal has to have an impact factor greater than: 1.730 to be in category A1, 1.154 to be in category A2 and so on. Columns 3 and 4 show, respectively, the number and percentage of publications in each category. The last column indicates the number of points that a professor receives when a paper is published in each category of journal.

Following the literature, we consider three groups of control variables that can affect the SET score. ${ }^{6}$ These variables are in vector $X_{i t}$. They are related to the characteristics of the students - the average grade in the course (GRADE), the percentage of female students in class (PFEM) and the fraction of students enrolled in class that answered the SET form (PRESP); courses - the class size (CSIZE) and a dummy for mandatory courses (MAND); and professors - number of years teaching at Insper (EXP), schooling (PHD), gender (GENDER), age (AGE) and the status of being a full-time or part-time professor (FULL).

\section{Results}

Table A.3 presents the results. In all regressions, (1) through (4), all control variables (students', courses' and professors' characteristics) were used. The coefficients of the variables GRADE, EXP and CSIZE appear more consistently as statistically significant. The coefficients of the variables reported have, in general, the expected signs. ${ }^{7}$ As can be seen, a higher average grade (GRADE) in the course positively affects the SET. The same result is obtained in Andrade \& Rocha (2012), indicating that a professor may "buy" a better evaluation by inflating the student's grade. Teaching experience (EXP) also positively influences the SET. This positive effect may reflect the professor's adaptation to the institution's environment and the student behavior (Andrade \& Rocha 2012). On the other hand, a greater class size (CSIZE) negatively affects the SET. The

\footnotetext{
${ }^{5}$ The list of questions that compose the SET form is: "organization and clarity", "communication skills", "exams format", "course content", "academic rigor", "academic experience", "market experience", "pragmatism", "interaction", "stimulating attitude", "stimulus for studies", "classroom dynamics" and "dedication". A more detailed description of the SET forms can be seen in Andrade \& Rocha (2012).

${ }^{6}$ For a review of the literature on the SET's determinants, see McPherson et al. (2009).

${ }^{7}$ For a discussion of the effects of these variables on SET, see McPherson et al. (2009). Evidence from Brazilian data can be found in Andrade \& Rocha (2012).
} 
sign of this coefficient probably reflects an "award" due to the higher level of attention given by the professor to any particular student in courses with small classes (Andrade \& Rocha 2012). In model (4), the coefficient of the variable AGE seems to suggest that, controlling for experience (EXP), there is no evidence of relevant human capital depreciation or student's discrimination against older professors.

In regression (1), in addition to the control variables, LAG_RSCH was added as an explanatory variable, which is the variable RSCH lagged in one year. The idea is that publication at time ' $t$ ' positively affects SET at time ' $t+1$ '. In other words, it may take one year for the effect of 'mastering more subjects' affecting SET to take place. The coefficient of LAG_RSCH is positive, as expected, and is statistically different from zero. This result suggests that, at least with a lag, research can induce a higher quality of teaching.

In regression (2), we check if it is possible that publication at time ' $t$ ' positively affects SET at time ' $t+2$ '. The variable LAG_RSCH was replaced by the variable LAG_RSCH2, which is the variable RSCH lagged two years. However, the coefficient is not statistically significant.

The use of indicators of past research performance is standard in the literature. But this type of information does not reveal whether research and teaching are complementary or substitutive activities, because research performance is associated to an effort taken in the past. In fact, it is difficult to know precisely when the effort in research activity to produce a given publication was put in place. The number of months/years necessary to have a paper published varies considerably even within the same journal. We tested two possibilities in this respect.

In regression (3), besides the control variables, FWD_RSCH was added as an explanatory variable, which is the variable $\mathrm{RSCH}$ one year ahead. In regression (4), besides the control variables, FWD_RSCH2 was added as an explanatory variable, which is the variable $\mathrm{RSCH}$ two years ahead. It is implicitly assumed that the main research activity occurred one year before publication, in the former model, and two years before publication, in the latter model.

The coefficient of FWD_RSCH is not statistically different from zero. However, the coefficient of FWD_RSCH2 is positive and significant. This last result suggests that teaching and research are complementary activities, and that research enhances the quality of teaching, at least as perceived by the students.

\section{Conclusions}

This paper aims to empirically test how research, measured by the number/ quality of publications, affects the quality of teaching, as perceived by the students through the SET, using a new dataset from a Brazilian higher education institution.

We found evidence that the process of doing research increases professor's knowledge, enhancing SET with a lag. Moreover, the results suggest that research activity seems to be complementary to teaching. The research activity seems to increase the quality of teaching at the moment that it is put in place, that is, both activities can be seen as 'mutually reinforcing'. 


\section{Acknowledgments}

We are grateful to Marcia Moura for authorizing the use of the data for this study. We would like to thank Rogério Costa for making the data used for this study available. Any views expressed are those of the authors' exclusively. The views expressed herein are those of the author(s) and do not necessarily reflect the views of the Insper. Bruno de Paula Rocha is grateful for the support received from CEDEPLAR and UFMG where part of this research was conducted. Needless to say, remaining errors and omissions are of our responsibility.

\section{Bibliography}

Andrade, E. \& Rocha, B. P. (2012), 'Factors affecting the student evaluation of teaching scores: Evidence from panel data estimation', Estudos Econômicos 42(1), 129-150.

Becker, W. \& Watts, M. (1999), 'How departments of economics evaluate teaching', American Economic Review 89(2), 344-349.

Binder, M., Chermak, J., Krause, K. \& Thacher, J. (2012), 'The teaching penalty in higher education: Evidence from a public research university', Economics Letters 117(1), 39-41.

Boyer, E. (1990), Scholarship Reconsidered: Priorities of the Professoriate, The Carnegie Foundation of the Advancement of Teaching, Princeton, NJ.

De Witte, K., Rogge, N., Cherchye, L. \& Puyen, T. V. (2013), 'Economies of scope in research and teaching: A non-parametric investigation', Omega 41(2), 305-314.

Fairweather, J. (2002), 'The mythologies of faculty productivity', The Journal of Higher Education 73(1), 26-48.

Ginsburg, T. \& Miles, T. J. (2015), 'The teaching/research trade-off in law: Data from the right tail', Evaluation Review 39(1), 46-81.

Greene, W. (2008), Econometric Analysis, sixth edition edn, Prentice Hall, New York.

Harmon, M. (2006), 'Business research and chinese patriotic poetry: How competition for status distorts the priority between research and teaching in U.S. business schools', Academy of Management Learning and Education 5(2), 234-243.

Link, A., Swann, C. \& Bozeman, B. (2008), 'A time allocation study of university faculty', Economics of Education Review 27(4), 363-374.

McPherson, M., Jewell, R. \& Kim, M. (2009), 'What determines student evaluation scores? a random effects analysis of undergraduate economic classes', Eastern Economic Journal 35(1), 37-51.

Zaman, M. (2004), 'Review of the academic evidence on the relationship between teaching and research in higher education', Research Report RR506. 


\section{Appendix A}

Table A.1: Descriptive statistics

\begin{tabular}{lcrrrrr}
\hline Variable & Obs & Mean & Median & Std. Dev. & Min & Max \\
\hline \multicolumn{7}{c}{ SET variables } \\
EVAL & 928 & 3.36 & 3.42 & 0.32 & 1.98 & 4.00 \\
\multicolumn{7}{c}{ Student's characteristics } \\
GRADE & 928 & 6.23 & 6.25 & 0.97 & 2.04 & 8.45 \\
PFEM & 928 & 28.45 & 29.02 & 7.87 & 0.00 & 57.14 \\
PRESP & 928 & 57.04 & 57.07 & 15.17 & 8.00 & 93.33 \\
CSIZE & 928 & 60.30 & 62.00 & 22.39 & 13.00 & 111.00 \\
MAND & 928 & 0.82 & 1.00 & 0.39 & 0.00 & 1.00 \\
EXP & 928 & 3.65 & 3.00 & 3.11 & 0.00 & 13.00 \\
PHD & 928 & 0.74 & 1.00 & 0.47 & 0.00 & 1.00 \\
GENDER & 928 & 0.81 & 1.00 & 0.40 & 0.00 & 1.00 \\
AGE & 928 & 40.17 & 39.00 & 7.56 & 24.93 & 66.00 \\
FULL & 928 & 0.35 & 0.00 & 0.48 & 0.00 & 1.00 \\
RSCH & 928 & 12.92 & 0.00 & 24.37 & 0.00 & 159.00 \\
\hline
\end{tabular}

Table A.2: Categories of Academic Journals in Economics

\begin{tabular}{llcrc}
\hline Category & $\begin{array}{l}\text { Minimum Impact } \\
\text { Factor }\end{array}$ & \# of publications & $\%$ & Points \\
\hline A1 & 1.73 & 24 & $12.70 \%$ & 40 \\
A2 & 1.154 & 33 & $17.50 \%$ & 32 \\
B1 & 0.73 & 42 & $22.20 \%$ & 24 \\
B2 & 0.484 & 36 & $19.00 \%$ & 20 \\
B3 & 0.329 & 28 & $14.80 \%$ & 12 \\
B4 & 0.049 & 25 & $13.20 \%$ & 8 \\
B5 & - & 1 & $0.50 \%$ & 4 \\
Total & - & 189 & $100.00 \%$ & - \\
\hline
\end{tabular}

Source: Insper. 
Table A.3: Fixed-Effects estimates

\begin{tabular}{|c|c|c|c|c|}
\hline Explanatory variables & (1) & (2) & (3) & $(4)$ \\
\hline \multicolumn{5}{|c|}{ Students' characteristics } \\
\hline GRADE & $\begin{array}{c}0.0994^{* *} \\
(0.0268)\end{array}$ & $\begin{array}{c}0.0821^{* *} \\
(0.0309)\end{array}$ & $\begin{array}{l}0.0675^{*} \\
(0.0279)\end{array}$ & $\begin{array}{l}0.0714^{*} \\
(0.0301)\end{array}$ \\
\hline PFEM & $\begin{array}{c}-0.00129 \\
(0.00174)\end{array}$ & $\begin{array}{c}-0.00203 \\
(0.00242)\end{array}$ & $\begin{array}{c}-0.00223 \\
(0.00185)\end{array}$ & $\begin{array}{c}-0.00327 \\
(0.00263)\end{array}$ \\
\hline PRESP & $\begin{array}{c}-0.000273 \\
(0.000837)\end{array}$ & $\begin{array}{c}-0.000166 \\
(0.00102)\end{array}$ & $\begin{array}{c}-8.67 E-05 \\
(0.00108)\end{array}$ & $\begin{array}{r}0.000377 \\
(0.00143)\end{array}$ \\
\hline \multicolumn{5}{|c|}{ Courses' characteristics } \\
\hline CSIZE & $\begin{array}{c}-0.00168^{+} \\
(0.000908)\end{array}$ & $\begin{array}{c}-0.00133 \\
(0.00115)\end{array}$ & $\begin{array}{c}-0.00172 \\
(0.00106)\end{array}$ & $\begin{array}{c}-0.00271^{*} \\
(0.00131)\end{array}$ \\
\hline MAND & $\begin{array}{c}-0.0959 \\
(0.0644)\end{array}$ & $\begin{array}{c}-0.00675 \\
(0.0779)\end{array}$ & $\begin{array}{c}-0.0800 \\
(0.0649)\end{array}$ & $\begin{array}{r}-0.0981 \\
(0.0869)\end{array}$ \\
\hline \multicolumn{5}{|c|}{ Professors' characteristics } \\
\hline EXP & $\begin{array}{l}0.0327^{*} \\
(0.0134)\end{array}$ & $\begin{array}{l}0.0300^{*} \\
(0.0149)\end{array}$ & $\begin{array}{c}-0.00478 \\
(0.0168)\end{array}$ & $\begin{array}{c}-0.00609 \\
(0.0171)\end{array}$ \\
\hline PHD & $\begin{array}{l}0.0989 \\
(0.0873)\end{array}$ & $\begin{array}{c}0.110 \\
(0.0899)\end{array}$ & $\begin{array}{c}0.00828 \\
(0.119)\end{array}$ & $\begin{array}{l}0.0935 \\
(0.0996)\end{array}$ \\
\hline GENDER & $\begin{array}{l}0.122 \\
(0.139)\end{array}$ & $\begin{array}{c}0.00767 \\
(0.145)\end{array}$ & $-\frac{0.00276}{(0.125)}$ & $\begin{array}{c}-0.0393 \\
(0.124)\end{array}$ \\
\hline AGE & $\begin{array}{l}-0.112 \\
(0.0787)\end{array}$ & $\begin{array}{r}-0.135 \\
(0.107)\end{array}$ & $\begin{array}{c}-0.0734 \\
(0.0947)\end{array}$ & $\begin{array}{c}0.148^{*} \\
(0.0727)\end{array}$ \\
\hline FULL & $\begin{array}{c}-0.0577 \\
(0.0564)\end{array}$ & $\begin{array}{l}0.0795 \\
(0.0667)\end{array}$ & $\begin{array}{c}-0.0685 \\
(0.0712)\end{array}$ & $\begin{array}{c}-0.133^{+} \\
(0.0727)\end{array}$ \\
\hline LAG_RSCH & $\begin{array}{c}0.000939^{+} \\
(0.000555)\end{array}$ & & & \\
\hline LAG_RSCH_2 & & $\begin{array}{l}0.000357 \\
(0.000548)\end{array}$ & & \\
\hline FWD_RSCH & & & $\begin{array}{c}-0.000799 \\
(0.000689)\end{array}$ & \\
\hline FWD_RSCH_2 & & & & $\begin{array}{l}0.00189^{* * *} \\
(0.000698)\end{array}$ \\
\hline Constant & $\begin{array}{l}7.592^{*} \\
(3.507)\end{array}$ & $\begin{array}{l}8.232^{+} \\
(4.279)\end{array}$ & $\begin{array}{l}5.815 \\
(3.543)\end{array}$ & $\begin{array}{c}-2.421 \\
(2.757)\end{array}$ \\
\hline Number of obs. & 502 & 329 & 502 & 329 \\
\hline R-squared & 0.19 & 0.189 & 0.112 & 0.163 \\
\hline Number of pairs professor/discipline & 128 & 85 & 128 & 85 \\
\hline
\end{tabular}

